\title{
Two case reports of distal upper limb weakness following influenza-like illness: an emerging pattern of para-infectious myositis in adults
}

\author{
Jakub Scaber ${ }^{1}$, Adam J Molyneux², Camilla Buckley ${ }^{1}$ and Alastair J S Webb ${ }^{1 *}$ (D)
}

\begin{abstract}
Background: Myositis is a recognised complication of numerous systemic viral infections including influenza. In adults the typical pattern is characterised by myalgia and marked proximal muscle weakness in upper and lower limbs and resolves slowly over weeks rather than days.

Case presentation: Here, we describe two male patients with myositis with an unusual distribution of weakness in the distal upper limbs, which both followed a flu-like illness and resolved spontaneously. Both patients had moderate elevations in creatine kinase, extensive negative serological investigations, normal nerve conduction studies and myopathic changes on electromyography.

Conclusions: In the para-infectious context, myositis is an important differential of acute distal upper limb weakness. This unusual pattern of acute muscle weakness should be recognised to avoid unnecessary in treatments. Similar cases in the recent literature in male patients between the ages of 25 to 55 are reviewed and suggest an emerging pattern of para-infectious myositis.
\end{abstract}

Keywords: Para-infectious, Muscle disease, Myositis, Case report

\section{Background}

Myositis is a recognised complication of numerous systemic viral infections including influenza [1]. In adults the typical pattern characterised with myalgia and marked proximal muscle weakness in upper and lower limbs and resolves slowly over weeks rather than days [2].

Here, we describe two patients with myositis with an unusual distribution of weakness in the distal upper limbs, which both followed a flu-like illness and resolved spontaneously. We review similar cases in the recent literature and postulate a new form of para-infectious myositis.

\footnotetext{
* Correspondence: alastair.webb@ndcn.ox.ac.uk

${ }^{1}$ Nuffield Department of Clinical Neurosciences, University of Oxford, West Wing Level 6, John Radcliffe Hospital, Headley Way, Oxford OX3 9DU, UK Full list of author information is available at the end of the article
}

\section{Case presentation}

\section{Case 1}

A 38-year-old medical professional with no relevant past medical history presented with a four-day history of fevers and rigors. On day three, he complained of neck pain and loose stools after taking amoxicillin. On day four, he awoke with difficulty using both hands and difficulty ascending stairs, as well as pain in his forearms and thighs. By the evening, the symptoms had progressed, and he was unable to hold cutlery, and complained of numbness in his fingertips.

Examination showed weakness of finger flexion (grade 4 ) and extension bilaterally (grade 4), with relative preservation of abduction (grade 4+). There was also mild weakness of hip flexion bilaterally (grade 4+). All

C C The Author(s). 2020 Open Access This article is licensed under a Creative Commons Attribution 4.0 International License, which permits use, sharing, adaptation, distribution and reproduction in any medium or format, as long as you give appropriate credit to the original author(s) and the source, provide a link to the Creative Commons licence, and indicate if changes were made. The images or other third party material in this article are included in the article's Creative Commons licence, unless indicated otherwise in a credit line to the material. If material is not included in the article's Creative Commons licence and your intended use is not permitted by statutory regulation or exceeds the permitted use, you will need to obtain permission directly from the copyright holder. To view a copy of this licence, visit http://creativecommons.org/licenses/by/4.0/ The Creative Commons Public Domain Dedication waiver (http://creativecommons.org/publicdomain/zero/1.0/) applies to the data made available in this article, unless otherwise stated in a credit line to the data. 
remaining upper and lower limb muscles were normal (grade 5). Reflexes were present and pinprick sensation was reduced in the distribution of the C6 dermatome bilaterally. Magnetic resonance imaging (MRI) of the whole spine and brachial plexus was normal. Creatine kinase (CK) was $2352 \mathrm{IU} / \mathrm{L}$ on admission, but blood tests were otherwise normal including a CRP of $2.8 \mathrm{mg} / \mathrm{L}$ and a negative blood culture, and lumbar puncture was acellular with a protein of $237 \mathrm{mg} / \mathrm{L}$ and normal glucose. Acutely, random serum glucose was $13 \mathrm{mmol} / \mathrm{L}$, but subsequently normalised. Nerve conduction studies were normal but electromyography (EMG) a day after admission showed mild abnormalities of the forearm muscles suggestive of myopathy (Table 1 and Fig. 1). The patient improved with return of normal arm power and walking after $48 \mathrm{~h}$. A muscle biopsy was not felt to be required given the improvement. The CK initially rose to 2703 but this improved to 765 a week later. Extensive serologic testing during the admission as well as influenza swabs were negative (Table 2).

\section{Case 2}

A 54-year-old man presented with a four-day history of fevers above $40^{\circ} \mathrm{C}$, rigors and sweats. On day three he developed leg weakness, struggling to climb stairs and getting out of the bath. There was associated thigh tenderness. Later that day, he also developed hand weakness, being unable to open bottles. On day four he required help to dress himself. There were no autonomic symptoms or sphincter disturbance and no sensory symptoms other than mild paraesthesia in the fingertips of both hands. He complained of mild neck pain.

Examination revealed distal more than proximal upper and lower limb weakness, particularly of finger flexion (grade 4 left, grade 4+ right) and extension (grade 4 bilaterally). There was also some weakness of hip extension (grade 4). Otherwise there was mild weakness in all muscle groups tested in the upper and lower limbs bilaterally (grade 4+), except for wrist extension and hip flexion, which were both normal (grade 5). Reflexes were present and sensation was normal. Computed tomography $(\mathrm{CT})$ of the head was normal. Admission blood tests demonstrated a CK of $987 \mathrm{U} / \mathrm{L}$ and CRP of $6.9 \mathrm{mg} /$ $\mathrm{L}$ and were otherwise normal. Cerebrospinal fluid (CSF) was acellular, with a protein of $484 \mathrm{mg} / \mathrm{L}$ and normal glucose. His condition improved spontaneously over the next 3 days and his CK returned to $180 \mathrm{U} / \mathrm{L}$, within the normal range. After another 5 days CK fell further to 80 U/L. Muscle biopsy was therefore deemed not to be required. EMG a week after presentation showed subtle myopathic changes, most convincing from the tibialis anterior and extensor digitorum communis, nerve conduction studies were normal. Influenza swab and extensive serologic testing during the admission was negative in this case also (Table 2).

\section{Discussion and conclusions}

The two cases presented here demonstrate clinical and laboratory studies consistent with a myopathic process, but with an atypical muscle pattern and predominant upper limb distal weakness. In both cases, no specific pathogen could be isolated. These two presentations occurred months apart and both patients recovered to full function within days to weeks. The main differential diagnosis considered initially in both cases was GuillainBarré syndrome (GBS), but the clinical and laboratory characteristics favoured a diagnosis of myositis for both patients. Given the mild sensory changes in the context of normal nerve conduction studies, we cannot completely exclude subclinical peripheral nerve involvement, and mild irritation of the lateral cutaneous nerve of the forearm by forearm muscle swelling or proximal radicular demyelination could have theoretically co-occurred but are not proven.

Benign acute myositis is well-recognised as a childhood illness, where it predominantly involves the calf muscles and is associated with influenza B virus. In adults, viral and post-infectious myositis is rarer but has been described in the context of influenza, mononucleosis, cytomegalovirus infection, echovirus 9 and viral hepatitis [1]. Cases share a characteristic pattern of prodromal myalgia followed by proximal muscle weakness, muscle tenderness, myoglobinuria and a slow recovery that is often incomplete by the time of discharge.

A novel pattern of distal pattern upper limb weakness following an influenza-like prodrome was first described during the H1N1 2009 influenza epidemic in Utah, with one of the cases also being a medical professional [3]. A similar case was reported in December 2017 in the UK [4]. There multiple are striking similarities between the four previously reported cases and the two cases presented here: All are men between the age of 25 and 54, with muscle tenderness CK elevations ranging from 500 to 3500 . While all six patients had notable weakness particularly of finger flexion and extension, four patients also had demonstrable proximal lower limb weakness, which was usually proximal. A febrile illness was reported to have preceded weakness by $2-5$ days in all cases except one, who reported flu-like symptoms starting a few weeks earlier. The weakness recovered to normal or near normal within 1 week from the start of the symptoms in the majority of patients.

Analogous to previous reports, we could not confirm an associated infectious agent in our patients on extensive serologic testing. The first patient presented towards the tail end of the seasonal influenza epidemic, with the prevalent strains being $B$ and $A(H 3)$, while the second 
Table 1 Electrophysiologic findings

\begin{tabular}{|c|c|c|c|c|c|c|c|c|}
\hline \multirow[b]{2}{*}{ Sensory Studies } & \multicolumn{4}{|c|}{ Patient 1} & \multicolumn{4}{|c|}{ Patient 2} \\
\hline & Lat & Amp & Velocity & & Lat & Amp & Velocity & \\
\hline & $\mathrm{ms}$ & $\mu \mathrm{V}$ & $\mathrm{m} / \mathrm{s}$ & & $\mathrm{ms}$ & $\mu V$ & $\mathrm{~m} / \mathrm{s}$ & \\
\hline R Median Digit 2 & 2.35 & 17.8 & 66 & & 2.75 & 7.8 & 52.7 & \\
\hline R Median Digit 3 & & & & & 3.05 & 7.5 & 47.5 & \\
\hline R Ulnar Digit 5 & 2.05 & 7.5 & 63.4 & & 2.05 & 5.5 & 56.1 & \\
\hline R Median Palm (Mix) & & & & & 1.65 & 23.6 & 48.5 & \\
\hline R Ulnar Palm (Mix) & & & & & 1.35 & 5.2 & 59.3 & \\
\hline L Median Digit 2 & & & & & 2.9 & 6.8 & 51.7 & \\
\hline L Median Digit 3 & & & & & 2.7 & 8.6 & 55.6 & \\
\hline L Ulnar Digit 5 & & & & & 2.25 & 6.1 & 51.1 & \\
\hline R Sural Calf & 2.1 & 12 & 47.6 & & 2.7 & 12.4 & 40.7 & \\
\hline L Sural Calf & & & & & 2.85 & 11.5 & 45.6 & \\
\hline R Superficial Peroneal & & & & & 2.75 & 7.8 & 41.8 & \\
\hline L Superficial Peroneal & & & & & 3.05 & 5.7 & 42.6 & \\
\hline \multirow[t]{2}{*}{ Motor Studies } & Lat & Amp & Velocity & F Lat & Lat & Amp & Velocity & F Lat \\
\hline & $\mathrm{ms}$ & $\mathrm{mV}$ & $\mathrm{m} / \mathrm{s}$ & $\mathrm{ms}$ & $\mathrm{ms}$ & $\mathrm{mV}$ & $\mathrm{m} / \mathrm{s}$ & $\mathrm{ms}$ \\
\hline R Median Wrist & 2.8 & 13.1 & & & 3.25 & 10.6 & & \\
\hline R Median Elbow & 7 & 13.2 & 59.5 & 26.1 & 7.85 & 9.9 & 60.9 & 28.6 \\
\hline L Median Wrist & 2.8 & 10.9 & & & 3.15 & 11.2 & & \\
\hline L Median Elbow & 6.65 & 11.1 & 65 & 26.05 & 7.95 & 11 & 56.3 & 28.6 \\
\hline R Ulnar Wrist & 2.4 & 10.7 & & & 2.45 & 13.9 & & \\
\hline R Ulnar Below Elbow & 5.85 & 10 & 75.4 & 26.05 & 6.8 & 14.5 & 57.5 & \\
\hline R Ulnar Above Elbow & & & & & 8.35 & 12.8 & 51.6 & 31.6 \\
\hline L Ulnar Wrist & 2.25 & 6.7 & & & 2.55 & 8.2 & & \\
\hline L Ulnar Below Elbow & 5.95 & 6.2 & 69.2 & 26.55 & 6.85 & 8.2 & 58.1 & 30.5 \\
\hline L Ulnar Above Elbow & & & & & 8.5 & 7.9 & 54.5 & \\
\hline R Com Peroneal Ankle & 3.2 & 7.1 & & & 4.25 & 9.2 & & \\
\hline R Com Peroneal Fib Head & 9.45 & 6.3 & 56 & 41.7 & 12.45 & 8.7 & 42.7 & 54.45 \\
\hline R Com Peroneal Knee & 10.65 & 6.5 & 66.7 & & 14.2 & 8.3 & 45.7 & 54 \\
\hline L Com Peroneal Ankle & & & & & 4.25 & 8.1 & & \\
\hline R Post Tibial Ankle & 4.75 & 18.8 & & & 4 & 15.7 & & \\
\hline R Post Tibial Knee & 11.8 & 15.8 & 58.2 & 44.9 & 14.05 & 12.6 & & 52.75 \\
\hline L Post Tibial Ankle & & & & & 3.6 & 10.5 & & \\
\hline L Post Tibial Knee & & & & & 13.95 & 8.7 & 45.4 & 55.6 \\
\hline \multirow[t]{2}{*}{ EMG } & MUAP & & & Recruit Pattern & MUAP & & & Recruit Pattern \\
\hline & Amp & Dur & Polyph & & Amp & Dur & Polyph & \\
\hline R Triceps & & & & & N & $\mathrm{N}$ & $N$ & $N$ \\
\hline R Extensor Dig Comn & $\mathrm{N}$ & $N / 1-$ & $\mathrm{N} / 1+$ & N/Fast & $1-$ & $\mathrm{N}$ & $1+$ & Fast \\
\hline R Flexor Dig Sup & & & & & N & $\mathrm{N}$ & $1+$ & N \\
\hline R First Dorsal Interos & $\mathrm{N}$ & N & N & N & $1-$ & N & $\mathrm{N}$ & N \\
\hline L Flexor Dig Sup & $\mathrm{N}$ & $N / 1-$ & $\mathrm{N} / 1+$ & $\mathrm{N} /$ Fast & & & & \\
\hline L Flexor Dig Prof IV & $\mathrm{N}$ & N/1- & $\mathrm{N} / 1+$ & $\mathrm{N} /$ Fast & & & & \\
\hline R Vastus Medialis & & & & & $1-$ & $\mathrm{N}$ & N & N \\
\hline R Tibialis Anterior & & & & & $1-$ & $\mathrm{N}$ & $\mathrm{N}$ & Fast \\
\hline
\end{tabular}

Table legend: Electrophysiologic findings for patients 1 and 2. There was no spontaneous activity on EMG in either of the two patients. EMG electromyography, Lat latency, Amp amplitude, $F$ Lat minimum $F$ wave latency, Mix mixed nerve, $N$ normal, $L$ left, $R$ right, Dur duration, Polyph polyphasia, MUAP motor unit action potential, Com common, Comn communis, Fib fibular, Post posterior, Dig digitorum, Sup superficialis, Prof profundus, Interos interosseus, Recruit recruitment 


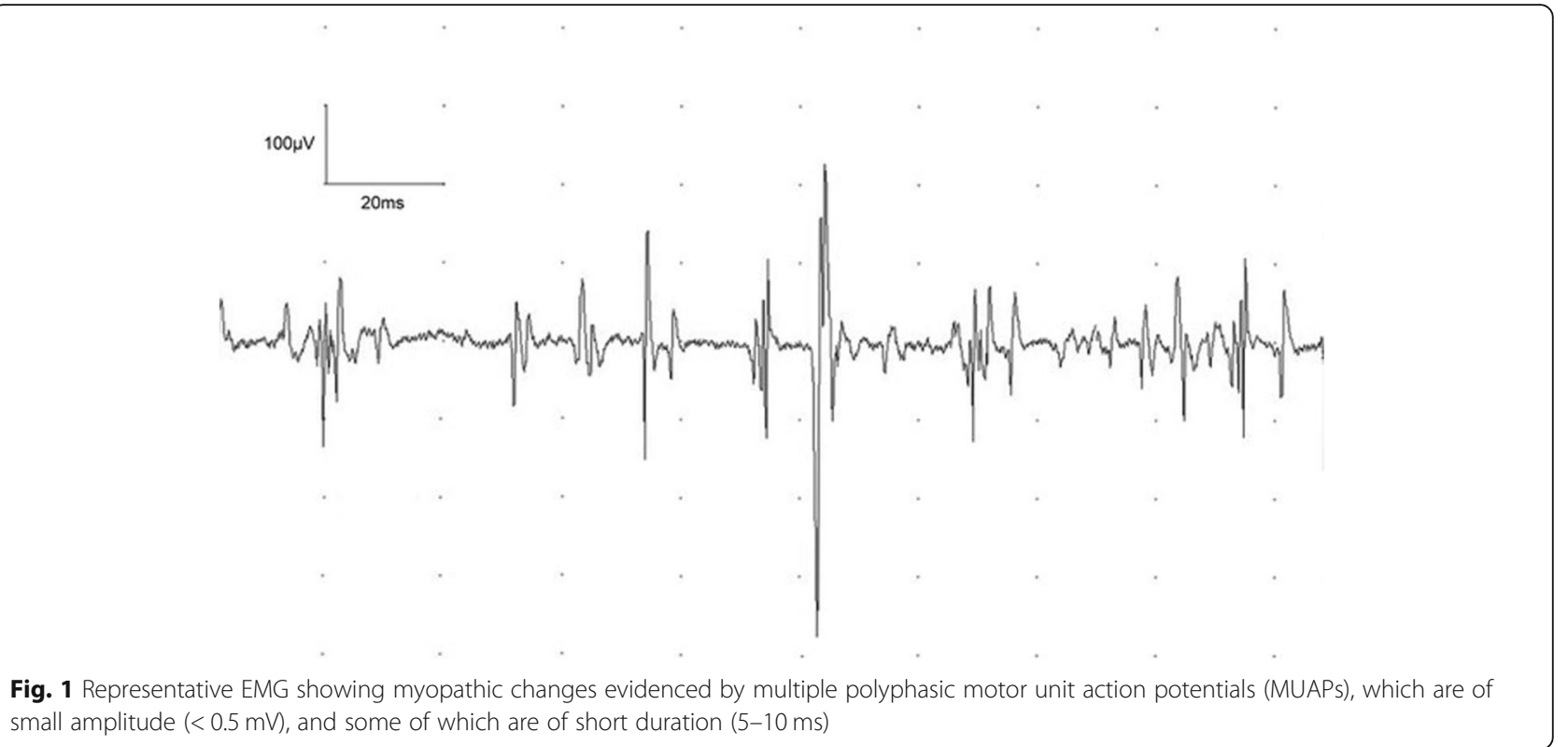

Table 2 Laboratory investigations

\begin{tabular}{|c|c|c|}
\hline & Patient 1 & Patient2 \\
\hline Influenza A/B \& RSV PCR & - & - \\
\hline CMV IgG & - & + \\
\hline CMV IgM & - & - \\
\hline EBV IgG & + & + \\
\hline EBV IgM & - & - \\
\hline VZV IgG & & + \\
\hline Hepatitis B serology & Immunised & - \\
\hline Hepatitis C serology & - & - \\
\hline Hepatitis E IgG & - & + \\
\hline Hepatitis E IgM & - & - \\
\hline HIV serology & - & - \\
\hline Parvovirus lgG & + & \\
\hline Parvovirus IgM & - & \\
\hline Borrelia serology & - & - \\
\hline Borrelia CSF line blot & & - \\
\hline Mycoplasma serology & - & - \\
\hline Syphilis serology & & - \\
\hline Antistreptolysin $\mathrm{O}$ titre & & - \\
\hline Myositis panel & - & \\
\hline GM1/GQ1b & - & - \\
\hline Antinuclear Antibodies & - & - \\
\hline
\end{tabular}

Table legend: Pertinent laboratory results for patients 1 and 2. CMV cytomegalovirus, CSF cerebrospinal fluid, EBV Eppstein-Barr virus, HIV human immunodeficiency virus, $R S V$ respiratory syncytial virus, VZV varicella zoster virus patient presented in the summer when influenza was not circulating in significant quantities. Although negative for respiratory viral PCR, all cases thus far had occurred during H1N1 influenza outbreaks, which led to the hypothesis that the pattern of distal upper limb weakness may be specific to this strain of influenza. This is unlikely given the timing of our cases. We hypothesize that a viral pathogen is the most likely explanation for the influenza-like febrile illness with a normal or only very mildly raised CRP in both patients. Given the very short time of 3 days between the onset of the flu-like illness and the onset of neurological symptoms, a direct effect of the virus on muscle cells causing necrosis [5] or an effect of the immune response to the virus is the most likely explanation [1]. The absence of a latency period means that a triggered secondary immune response, as is seen in post-infectious diseases such as GBS, is unlikely [6].

The cases reported here provide further evidence for an emerging pattern of para-infectious myositis, unusually involving the distal upper limbs. Myositis should therefore be considered by clinicians seeing patients with wrist and hand weakness following influenza-like illness. Confident recognition of this muscle pattern and distinction from commoner causes of acute distal upper limb weakness, such as Guillain-Barre syndrome and inflammatory myopathies, is paramount to avoid unnecessary investigations or treatments including muscle biopsies, steroids or intravenous immunoglobulin [7]. Treatment for para-infectious myositis is symptomatic and renal function should be monitored alongside CK and managed appropriately. 


\section{Abbreviations}

ANA: Antinuclear antibodies; CMV: Cytomegalovirus; CRP: C reactive protein: CSF: Cerebrospinal fluid; EBV: Eppstein-Barr virus; GBS: Guillain-Barré syndrome; HIV: Human immunodeficiency virus; PCR: Polymerase chain reaction; RSV: Respiratory syncytial virus; VZV: Varicella zoster virus

\section{Acknowledgements}

Not applicable.

\section{Authors' contributions}

JS: data collection, drafting and revision; AM: data collection, revision; CB: data collection; AW: data collection, revision. All authors read and approved the manuscript.

\section{Funding}

AW's salary is funded by a Wellcome Trust clinical research career development Fellowship (206589/Z/17/Z). This study did not receive any other dedicated funding

\section{Availability of data and materials}

Not applicable.

\section{Ethics approval and consent to participate}

Waived.

\section{Consent for publication}

Both patients gave informed written consent for publication.

\section{Competing interests}

The authors declare that they have no competing interests.

\section{Author details}

1 Nuffield Department of Clinical Neurosciences, University of Oxford, West Wing Level 6, John Radcliffe Hospital, Headley Way, Oxford OX3 9DU, UK. ${ }^{2}$ Department of Clinical Neurophysiology, Oxford University Hospitals,

Foundation Trust, Oxford, UK.

Received: 21 January 2020 Accepted: 4 June 2020

Published online: 10 June 2020

\section{References}

1. Crum-Cianflone NF. Nonbacterial myositis. Curr Infect Dis Rep. 2010;12(5): 374-82.

2. Naylor CD, Jevnikar AM, Witt NJ. Sporadic viral myositis in two adults. CMAJ. 1987;137(9):819-21.

3. Gibson SB, Majersik JJ, Smith AG, Bromberg MB. Three cases of acute myositis in adults following influenza-like illness during the H1N1 pandemic. J Neurosci Rural Pract. 2013:4(1):51-4.

4. Datta S, Cosgrove J, Alam T, Ford HL. Unusual case of bilateral hand weakness. Pract Neurol. 2017;17(6):479-81.

5. Agyeman P, Duppenthaler A, Heininger U, Aebi C. Influenza-associated myositis in children. Infection. 2004;32:4.

6. Hahn AF. Guillain-Barré syndrome. Lancet. 1998;352(9128):635-41.

7. Chanson JB, Dakayi C, Lannes B, Echaniz-Laguna A. Benign acute myositis in an adult patient. BMJ Case Rep. 2018;2018:bcr-2017-223493.

\section{Publisher's Note}

Springer Nature remains neutral with regard to jurisdictional claims in published maps and institutional affiliations.

Ready to submit your research? Choose BMC and benefit from:

- fast, convenient online submission

- thorough peer review by experienced researchers in your field

- rapid publication on acceptance

- support for research data, including large and complex data types

- gold Open Access which fosters wider collaboration and increased citations

- maximum visibility for your research: over $100 \mathrm{M}$ website views per year

At $\mathrm{BMC}$, research is always in progress.

Learn more biomedcentral.com/submissions 